\title{
The New Human Tissue Bill: Categorization and Definitional Issues and their Implications.
}

\author{
BRONWYN PARRY
}

\begin{abstract}
While providing a welcome and timely revision of the now outdated Human Tissue Act of 1961, the newly introduced Human Tissue Bill of 2004 contains a number of anomalies in its drafting that threaten to undermine its effectiveness in practice. Two examples: the first relating to the status of 'remnant or waste' tissue and the second relating to the status and use of artefacts created from collected tissue are here employed to illustrate some of the definitional and categorical inconsistencies that are evident in the Bill. Having identified these, the paper then provides an analysis of how these inconsistencies may act to severely constrain the ways in which retained tissue may be lawfully employed in biomedical research and to confuse questions of who may, or may not, have formally recognised interests in types of processed human tissue.
\end{abstract}

\section{Introduction}

The new Human Tissue Bill of 2004 has been drafted largely in response to concerns raised by events at the Bristol Royal Infirmary and the Royal Liverpool Children's Hospital (Alder Hey). As the Kennedy ${ }^{1}$ and Redfern ${ }^{2}$ inquiries established, organs and tissue from children who had died at these two hospitals had been removed, stored and used without proper consent, a matter of grave concern. A subsequent census by the Chief Medical Officer for England (2000) ${ }^{3}$ and the Isaacs Report $(2003)^{4}$ revealed that the practice of retaining, storing and using organs and tissue taken from adults and children without proper consent had become relatively commonplace in the period from 1970 to 1995. There was a considerable expectation that the new Human Tissue Bill would provide a welcome means of remedying the insufficiencies in existing legislation that had allowed these wholly unacceptable events to occur and that it would establish a clear and workable framework of governance for the collection and use of human tissues and organs in the UK.

Following the tabling of the first draft of the Bill in the House of Commons on the 3rd December 2003, it became evident, however, that the new Bill contained a number of vagaries and inconsistencies that threatened to undermine its effectiveness in practice and constrain vital medical research in ways perhaps not fully anticipated by those responsible for its introduction. In order to draw attention to the implications of the passage of the Bill, and its likely effect on biomedical research in the UK, an interdisciplinary Human Tissue Bill workshop (jointly sponsored by the Wellcome Trust-funded King's College Bioethics Project and the Cambridge Genetics Knowledge Park) was held at King's College, Cambridge in January 2004. The workshop, which drew together 40 invited delegates with expertise in medical research, law, pathology, and the social sciences, identified a number of areas of 
immediate concern. These, and a series of possible amendments to the Bill, were robustly debated, and the latter circulated within the broader bio-medical community for further consultation and refinement before being advanced for consideration. The Bill returned to the House of Commons for its report stage and third reading on the $29^{\text {th }}$ June, 2004. Of the nearly 100 amendments that were eventually tabled, four significant ones were finally adopted. The Bill is currently being vigorously debated in the House of Lords.

As an online briefing paper produced by the co-ordinators of the workshop provides a detailed summation of the main shortcomings of the Bill ${ }^{5}$ (as originally drafted), my aim here is to employ just two examples (the first relating to the status of 'remnant or waste', the second relating to the status and use of artifacts created from collected tissue) to illustrate some of the ways in which the Bill was initially insufficient, how subsequent amendments may address these insufficiencies, and what may yet be required to ensure that the Bill operates in an effective and equitable manner. What becomes evident from this analysis is that many of the most potentially problematic aspects of the Bill arose out of definitional and categorical inconsistencies - that is to say, inconsistencies in the way the Bill defines its subject matter and categorizes the uses to which that subject matter might be put, both medically and commercially. Unless remedied, they have the potential (now somewhat, but not fully ameliorated), to severely restrict how retained tissue may be used in biomedical research and to confuse questions of who may or may not have formally recognized interests in types of processed human tissue - for example, property rights in them or rights to deal in them commercially. The following sections outline the primary issues and areas of remaining concern.

\section{Remnant and 'Waste' Tissue: To what should the Human Tissue Bill apply?}

One of the most important outcomes of the Alder Hey and Bristol enquiries was the recognition that there was a very serious disjunction or lack of correspondence between pathologists' and the general public's perceptions of what might constitute 'a sample of tissue'. Many parents were gravely distressed to discover that retained 'samples of tissue' had in some cases, included whole organs or very sizeable parts of them. Some wished only these identifiable organs or parts to be returned to them for burial, others argued that as all body parts were as significant as each other, all retained samples of tissue should be returned to them, even those which had been subsequently turned into technological artefacts such as tissues slides and blocks. It became clear politically, that, in the circumstances, it could well be construed as an affront to bereaved parents to suggest that body parts be 'hierachised' in any way under the new law. It is as a direct consequence of this, I believe, that the new legislation adopts, in Section One of the Bill, a deliberately broad definition of the category of objects to which the Bill will generally apply. This includes all "relevant material of which the body consists, or which it contains'. Relevant Material is explicitly defined in Section 58 (1) as 'material, other than gametes, which consists of, or includes human cells'.

Genomics, Society and Policy, Vol.1 No.1 (2005) ISSN: 1746-5354

(C) CESAGen, Lancaster University, UK. 
Employing such a broad basic definition of the material to which the Bill would apply was useful to the drafters as it enabled them to send out an unequivocal signal to a mistrustful general public that the Bill would legislate against all unconsented uses of every conceivable variety of human bodily part no matter how obtained or constituted. The difficulty lay in the fact that the definition was also, necessarily, wholly unnuanced - few distinctions were made between different types of body parts and bodily derivatives and little account was taken of the quite different circumstances in which they were acquired or produced. Each were to be treated commensurately under the new law despite the fact that, in general, the interests (both personal and legal) that individuals have in these materials is mediated by factors such as the nature of the material, (what type it is, its size, etc.); the manner in which was collected; and the prospective uses to which it might be put. The broadness of the basic definition of the 'relevant material' to which the Bill would apply was such that that a number of exceptions had to be made to it in order to render the Bill operable in practice. The rationales for excepting them were also, however, characterized by inconsistencies, as we shall see.

Sections 1.1 of the first draft of the Bill, set out the consents required to lawfully remove, store and use organs and tissues. Very significantly, no distinction was here made between the specificity and scope of the consent required for the storage and use of 'relevant material' from that of the dead or that of the living for purposes set out in Part One of Schedule I - which included education or training relating to human health and general medical research into disorders or functioning of the human body. Neither, by consequence of the application of the all-encompassing definition of 'relevant material' was any distinction made between the types of material to which the legislation would pertain. No distinction was made, for example, between a whole organ removed post-mortem and a sliver of tissue or even a few cells taken as a biopsy for diagnostic purposes during life. The draft Bill had it that it would be possible to employ tissue obtained from a living subject without their consent, but only for the very limited range of uses set out in Part 2 of Schedule I. These included clinical audit, education or training incidental to medical diagnosis or treatment, quality assurance and public health monitoring. The explanatory notes that accompany the Bill make clear that these activities are exempted from the usual consent requirements, as they are 'considered intrinsic to the proper conduct of a patient's treatment or are necessary for the public health of the nation'. 6

This drafting gave rise to several serious concerns. The first was that the new legislation, if enacted as drafted, would make it a criminal offence to store, remove or use any 'relevant bodily material' from a living person for the purposes of education and training, or research into functioning or disorders of the human body, without their 'appropriate' consent. It became immediately evident that this would, as a consequence of the broadness of the definition of 'relevant bodily material,' necessarily include all blood samples and tissues taken for diagnostic purposes during a patient's lifetime along with any remnant or waste tissue retained following surgery, and cells aspirated from biopsied materials during surgery or diagnosis, even urine and sputum. Such materials have long provided an invaluable resource for use in biomedical research, training and education, and there was a strong consensus within the 
medical and research communities that to make it a criminal offence to utilise them without the consent of the individual would act to profoundly constrain essential research activities.

As a direct consequence of the circumstances of its production, the first draft of the Bill was underwritten by a presumption that individuals have an undifferentiated relationship to their extracted body parts: that they consider all body parts to be as significant as each other, regardless of their form or the circumstances of their detachment. While parents, partners and significant others often express this sentiment in relation to the collection and use of body parts taken from those to whom they have a duty of care, ${ }^{7}$ own research and that conducted by the Peterborough Tissue Resource Centre ${ }^{8}$ suggests that individuals do not always display the same degree of sentiment about their own body tissues. Many seem to care remarkably little about the fate of organs or tissues lost to them in life, and are particularly unsentimental about tissues, cells or fluids extracted for surgical or diagnostic purposes. Some however, feel more strongly about whole organs removed during post-mortems as this is a practice that threatens the principle of maintaining bodily integrity in death to which many people subscribe.

In 1995 the Nuffield Council Report "Human Tissue: Ethical and Legal Issues" controversially argued that any material excised surgically, could be regarded as "abandoned" or "discarded" by the patient. As the material was res nullius - a thing which never had an owner, or which had, but lost its owner- it would therefore become available to be employed for a variety of legitimate purposes, including research. Following the Alder Hey and Bristol enquiries, the MRC set out more restrictive guidance on the use of such materials, recommending that, whenever practicable, individual patient consent be obtained for use in research of human material surplus to clinical requirements. This principle was enshrined as a legal requirement in the first draft of the Bill despite the fact that the Response to Human Bodies Human Choices Report recommended that 'any new legislation take account of the different emotions attached to human organs and tissue removed from the living and those who have died' ${ }^{9}$.

There seemed consequently to be very sound reasons to consider re-drafting the Bill in order to create a distinction between a) the use of residual tissues taken with proper consent in a clinical situation and b) the explicit removal and storage of whole organs at post-mortem specifically for research or other purposes. While explicit consent would be required for the latter, it did not seem inappropriate to consider whether it might be made lawful to use the former for research and other ethically approved purposes without specific consent.

A second very serious concern was that relating to the specificity of the consents required to use residual tissue in a lawful manner. Although the Bill introduced criminal sanctions for those found to have retained or used such material without 'appropriate consent', at no point did it state on the face of the Bill what form such a consent would take - whether, for example, it would be satisfied by the procurement of a verbal or written consent, and whether or not a broad consent given at the time of 
treatment would be sufficient to cover prospective or unanticipated uses of the material. The logistical implications of having to secure a detailed consent from individuals to use their remnant tissue and other bodily samples for purposes within Schedule 1 (as initially drafted) were bought home by some initial estimations proffered by Professor Peter Furness ${ }^{10}$ who calculated (based on figures extrapolated from workload data in the Leicester region of the NHS that some 150 million specimens were collected each year from living persons in Britain. Allowing even just one minute per patien $t$ to explain the consent procedure, offer information and record the patients response, Furness estimated that fulfilling the consent requirements as first drafted would demand at least an extra 1,339 full time jobs and substantial refinements of existing computerised recording facilities. ${ }^{11}$

A third concern was the apparently arbitrary and unsustainable distinctions that were being drawn in the categorization of research activities. While, for example, epidemiological research for the purposes of public health monitoring and clinical audit was placed in schedule 2, and thus able to be carried out on remnant tissue from living persons without their explicit consent, all other types of general epidemiological research requiring the use of remnant samples were placed outwith Schedule 2. As members of the Academy of Medical sciences noted in their January statement on the matter there is, in reality, often very little distinction between public health monitoring and clinical audit research, and general epidemiological research carried out to determine the distribution and determinants of disease risk in human populations. ${ }^{12}$ Despite this they were to be categorised quite differently in law under the new Bill. So, while determining the proportion of women attending antenatal clinics who are hepatitis B positive or HIV positive would have been defined as an example of 'public health monitoring', a Schedule two activity not requiring consent, establishing the relationship between the proportion of people with and without heart disease who are Chlamydia positive to see if Chlamydia infection may be a cause of heart disease, would be categorised as a Schedule I activity requiring consent. As they noted, there seemed no logical reason why these two activities, which are fundamentally commensurate, should be treated as categorically distant or requisite of different treatment in law, at least as far as consent requirements are concerned. Why this research, or indeed all research carried out in connection with disorders, or the functioning of the human body could not reasonably be categorized as also being "intrinsic to the proper conduct of a patient's treatment or necessary for the public health of the nation" - the rationale for placement of an activity in Schedule 2, was also unclear.

\section{Amendments and outstanding issues}

Following the workshop, and a period of intensive lobbying by bio-medical research groups and institutions, a number of amendments were made to the Bill. The new sections 1(7); 1(8); 1(9) and Schedule 5 Paragraph 10 have the operative effect of placing research in connection with disorders or functioning of the human body into Schedule 2 of the Bill without doing so overtly. The need to effect this transference was evident, however the political sensitivities were such that this outcome had to be achieved through a somewhat circuitous route. Sections 1 (7-9) of the Bill allow tissue 
from the living to be stored and used for some education and training purposes and for research in connection with disorders or functioning of the human body (including genetic research - Schedule 5 Paragraph 10) without consent if two criteria are met: The first is that the research be "ethically approved in accordance with regulations made by the Secretary of State" and the second is that it be "carried out in circumstances such that the person carrying it out is not in possession, and not likely to come into possession, of information from which the person from whose body the material has come can be identified". Obscurantist language aside, this means anonymised, such that the identity of the donor can no longer be linked to, or derived from the sample.

This very substantive and warmly received set of amendments will undoubtedly ensure that most types of essential bio-medical research conducted in the UK can now proceed with appropriate safeguards but without being overly consumptive of precious financial or administrative resources. While there is much to be welcomed in the amendments some anomalies remain that will impede vital research initiatives unless they are remedied before the final passage of the Bill into law. The most pressing of these relate to the requirements for anonymisation. While in most cases it will not be necessary for researchers to link tissue samples to clinical information about the donor, in some areas of epidemiological research, particularly genetic research, it will remain essential to do so. At Georgetown University in the United States for example, there exists an archived bank of nearly 2000 samples of tissue drawn from women with breast cancer that is linked both to clinical data on their treatment: type and duration, response to treatment, relapse and survival rates, as well as sociodemographic and genetic data on potential risk factors, such as alcohol, reproductive history and occupation. ${ }^{13}$ Although such information can be irreversibly anonymised in order to prevent identification of the donor (as would be required under the new HTB as currently drafted) it is not always desirable to do so.

As Bill Lowrance noted in his 2002 report for the Nuffield Trust on the secondary use of personal data in health research, ${ }^{14}$ there are a number of crucially important reasons for retaining the potential to re-identify and/or re-trace donors. These include the need to allow validation or auditing of the data; to request additional data if necessary; to inform a physician or patient of useful findings; and to facilitate later research followup. Reversible anonymisation allows patient identifiers to be replaced with a code that can be accessed only by a select few 'key holders' who have the power to re-associate the de-identified data with the original identifiers should this become necessary to undertake any of the tasks outlined above. Unless the Bill is redrafted such that the definition of anonymisation is clarified to ensure that reversible anonymisation will be acceptable in certain specific circumstances, the quality of much epidemiological research will be seriously compromised.

As the wording of the Bill stands at present, it seems that it will also be impossible for any clinician who is in direct contact with a patient to undertake any form of research on that patient as he or she would inevitably be in possession of identifying information about them. While the intention is to ensure that the privacy of the research subject is not compromised the current wording will also ensure that no 
clinician will be legally entitled to undertake research on any of his or her patient groups even if the research is essential and has been approved by an ethics committee. Ron Zimmern, Director of the CGKP notes that the Medical Research Council have advocated that the Bill should permit the use of tissue for research without anonymisation, if the results cannot effect the person's or the families interests and where the patient has been informed at the time the sample was taken that their material may be used for research subject to approval from an appropriately constituted research ethics committee, and that this kind of exception ought to be formalized in the new legislation to prevent criminalisation of legitimate research activities undertaken by clinicians on known patient groups. ${ }^{15}$

While the amendments have seen the use of tissues from living donors for the purposes of education and training relating to human health moved from Schedule 1 to Schedule 2 of the Bill, the use of tissues from either living or dead persons for the purposes of education or training relating to research remains an activity for which consent much always be secured. The rationale for creating a categorical distinction between the two is weak at best, if not wholly unsustainable and there again seems no logical reason why it should not become lawful to use remnant tissue from living donors for any purposes relating to bio-medical education or training subject of course to the MRC's caveats that it not adversely affect their or their families interests; that they have been informed at the time that the sample was taken that it may be used for this purpose; that its use in training or education be subject to the usual ethical approvals; and that they may opt-out if they wish.

Finally, while Section 49 of the Bill provides that it will be lawful for material that has come from a person's body (alive or dead) in the course of treatment, diagnostic testing or whilst participating in research that has ceased to be used or stored for use for a purpose specified in Schedule I to be dealt with as waste - the legislation still does not make clear what the status of this 'waste' will be. If it were to be declared res nullius then it could become lawfully available for use for purposes within or outwith Schedule1. However, as it is currently drafted, Schedule I activities appear to remain prohibited notwithstanding that the material has been officially declared to be waste.

\section{The Status and Use of 'Technological Artifacts': Prohibition of Commercial Dealings}

The broad definition of 'relevant material' that is applied generally in the Act "material, other than gametes, which consists of, or includes human cells" is so all encompassing that a series of different exceptions had to be made to it in order to render the Bill operable. In Section One of the Bill, which addresses the removal, storage and use of such material, several exceptions are made to the general definition of relevant material: for embryos outside of the body (as they are dealt with under separate legislation), but also for hair and nail from the body of a living person. Some queries have been raised about the raison d'etre behind these latter exceptions. While both are evidently necessary to prevent criminalisation of unproblematic domestic acts such as cutting and retaining nail and hair they also create an inconsistency in that both, but hair in particular, while consisting of acellular keratin for most of it length, 
nonetheless contains cells at the root tip. At present these cells could presumably be used for all of the purposes in Schedule One without consent, even though consent provisions would normally apply if the material was not excepted. Given this, we might question the logic of this exception, or the every least its practicability in application. As an entire hair will certainly 'include human cells', it may well be asked whether the cells at the root of the hair are included or excluded material for the purposes of the definition, or at what point along the axis of the hair the exception come into force?

The exceptions that are made in Section One to the definition of relevant bodily material are not, however, consistently applied. They are withdrawn in Sections 50 (5) and Schedule 5 that deal with DNA analysis for obvious reasons, as hair follicles are, for example, a prime source of DNA; and added to in the Section 32 which relates to the Prohibition of Commercial Dealings in Human Material. This episodic and ad-hoc revision of basic definitions on a section-by-section basis exemplifies the difficulty that the drafters have had in trying to accommodate the very different relationships that different constituencies have to bodily materials when in different forms. So, for example, while it is clear that the drafters have no wish to insist that wigmakers obtain consent from every individual from whom they source hair, they also recognise that they must carefully control those who wish to access the very same materials for the purposes on non-consensual genetic testing - such as paternity testing. Relying on the rather crude mechanism of definitional changes provides one means of accomplishing this work however it comes with an attendant risk of confusing practitioners and making them very uncertain as to what uses they may lawfully make of what materials, in what circumstances.

This variability in the application of the definition may also give rise to further difficulties - perhaps even a loss of public confidence in the ability of the Bill to regulate activities that the public find objectionable or unacceptable. One of the most consistent findings to emerge from a series of recent public consultations was the abhorrence with which members of the general public view the practice of commercialising the use of human organs or tissues or of dealing in them for profit. The Bill, in dealing with these issues, creates new offences in relationship to the supply and use of whole bodies and 'relevant bodily materials' for profit - in effect for reward beyond the cost of supply - however it creates exceptions for several categories of these relevant bodily materials. These include on this occasion: gametes, embryos, hair and nail from the body of a living person, and, a notable other: "material which is the subject of property because of an application of human skill".

Under Section 59 (7) of the amended Bill, which deals with general interpretation, we find another curious, but related, exception. It is here stated that: "For the purposes of this Act, material shall not be regarded as from a human body if it is created outside the human body". An explanation for the apparently tautological nature of this statement can be found in the explanatory notes that accompany the Bill. They give a fuller exposition of what this exemption might mean in practice, noting that "cell lines are also excluded by virtue of clause 59(7), as is any other human material created outside the human body". The intention of the Bill here is clear. In this 
biotechnological age, human organs and tissue are often processed in quite complex ways, many of which demand the investment of considerable work and skill. The Bill anticipates that those 'technological artifacts' that are created from relevant bodily material must be excepted from regulation under this Bill as they are likely to be claimed as a form of property by the scientists or technicians that have applied their skill in their manufacture.

It is by no means clear, however, how these sections of the Bill will be interpreted by the new Human Tissue Authority - the agency charged with responsibility for overseeing the implementation of the Act. While it is likely that the Authority may look to the common law for guidance on the question of how much - or how little skill or invested technical labour must be applied to human tissue to make it the subject of property, they are unlikely to find an unambiguous answer there. The existing case law Doodeward v Spence; Dobson v North Tyneside Health Authority; and R. Vs Kelly; has historically, as Grubb has noted, been even less persuasive of any settled position than has legislation. ${ }^{16}$

It could be argued that highly characterized collections of especially prepared organs fixed in formalin; mounted sections of tissue; or especially selected, stained and mounted collections of histopathological slides that relate to a specific disease condition; may all constitute 'works' or technological artifacts that are the product of the investment of a considerable degree of highly specialized technical labour. In which case, pathologists could rightfully apply for them to be exempted from the regulation governing commercial dealings in human materials under Section 32 (9) of the Bill on the grounds that they constitute their personal property. This may well be an entirely appropriate reflection in law of the way in which relationships to biological materials must be re-cast as the materials themselves are re-made into new, collectively constructed objects in which many parties may have rights or interests.

It is not clear however, that the basis for extending this right, or the limitations of the right will be immediately evident, or embraced, by those whose tissue is employed in their manufacture.

If, as stated, a key purpose of the Bill is to inject clarity into the law relating to the uses of archived human tissue, it is unfortunate that it has left this matter so illdetermined in the legislation as it currently stands.The Bill does not establish, for example, whether the fixing of specimens or the production of slides (or both) would constitute an input of sufficient work and skill to warrant the grant of extra rights in relation to these objects, and indeed, whether those rights would be merely rights of lawful possession or if they might be proprietary rights. On March the $26^{\text {th }}$ this year Mr. Justice Gage handed down his judgment in the Nationwide Organ Group Litigation case - an action bought by parents of children whose organs were retained at Bristol and Alder Hey hospitals to establish whether the defendant hospitals had, in so doing, committed the tort of wrongful interference with a body; were negligent; and had breached Article 8 of the Human Rights Act. ${ }^{17}$ It is interesting to note that he determined that in cases where body parts had been retained following a coroners' post-mortem examination that there were no grounds for sustaining a tort of wrongful interference with the body as the claimants had no right of burial and possession of 
organs lawfully removed and retained at a coroner's post-mortem, and that, moreover, the application of work and skill that had been applied to retained organs during the post-mortem and histopathological process was sufficient to entitle the hospitals to lawful possession of the organs, as property.

He determines at Section 148 for example, that "In my judgment the principle that part of a body may acquire the character of property which can be the subject of rights of possession and ownership is now part of our law. In particular, in my opinion, Kelly's case establishes the exception to the rule that there is no property in a corpse where part of the body has been the subject of the application of skill such as dissection or preservation techniques. The evidence in the lead cases shows that to dissect and fix an organ from a child's body requires work and a great deal of skill, the more so in the case of a very small baby such as Rosina Harris. The subsequent production of blocks and slides is also a skilful operation requiring work and expertise of trained scientists." He goes on to state unequivocally at 160 that: "For the avoidance of doubt, in my opinion, in the three lead cases the evidence of the pathologists shows that the work and skill applied to the parts of the body removed at the post-mortem is sufficient to come within the Doodeward exception. They are therefore capable of being subject to rights of possession", and crucially at 257 that "in my opinion, following the post-mortem, the hospital acquired proprietary and possessory rights to the organs (my italics). The question that remains is how the new provisions of the Human Tissue Bill can or will be interpreted in light of this judgment and what the implications of that interpretation might be? It is unfortunate that this issue has not been discussed or resolved in the drafting of the new Bill as it will undoubtedly become more pressing in years to come and may well be the subject of further litigation.

A final, but potentially equally contentious issue that may attract further attention is the exception that has been made at 59(7) for material from a human body that is created outside the human body. While this exemption is designed to place technologically produced human materials - such as cloned cells and cell lines beyond the jurisdictional reach of the Bill, it is not clear that there will be widespread public support for exempting materials that are derived from the human body (such as human cells) simply because they are produced by a technological process. If the general public consider it unacceptable to profit from a commercial use of a person's cells they are unlikely to agree that it is acceptable to profit from the use of their cloned cells. The furore and legal battles that have surrounded the commercialisation of the HeLa and Mo cell lines in the US suggest that individuals may continue to believe that they have interests in their bodily materials, even when reproduced through a technological process. If the exception is being made on the basis that they constitute a technological work produced through the applied skill and work of a specialized technician then, in the interests of consistency and clarity, it might be best if any exception be made on this basis alone. 


\section{Conclusion}

The new Human Tissue Bill provides a timely revision of the existing Human Tissue Act of 1961 and offers a much more comprehensive regulatory framework for the retention, storage, and use of human tissue in the UK than has been available to date. Following a number of very significant recent amendments to the Bill there is every reason to be hopeful that it will meet its stated goal of balancing the rights and expectations of individuals with those of practitioners involved in providing research, education, training, pathological and public health surveillance services to the population as a whole. However several further revisions may yet provide remedies for some remaining, but significant anomalies. The first revision would make clear that reversible and linked anonymisation would be permitted, particularly in general epidemiological research. The second would ensure that all forms of education or training whether related to research or human health would be able to be undertaken on remnant tissue derived from living persons without their explicit consent. The third would allow for the provisions for anonymity in the use of tissues from living persons to be waived in certain specific circumstances (for example, when a clinician would wish to conduct research on a patient group known to him or her), if undertaken with appropriate ethical approval. Finally, the drafters may wish to re-examine the basis of some exceptions: those for hair; for material which is the subject of property because of an application of human skill; and for material created outside the human body, to consider whether they are fully operable or necessary and whether the Bill might benefit further from tightening, clarifying or even expunging those that serve to obfuscate understanding or implementation of the Bill as it currently stands.

\section{Acknowledgements}

I would like to thank my colleagues at the Cambridge Genetic Knowledge Park: Ron Zimmern, Alison Hall and Kathy Liddell for their help in conceptualizing these issues and the Wellcome Trust for funding this research. Any errors remain my own.

\footnotetext{
1 I. Kennedy. 2001. Learning from Bristol: the report of the public inquiry into children's heart surgery at the Bristol Royal Infirmary 1984 -1995. London. Government Stationary Office.

2 M. Redfern. 2001. The Royal Liverpool Children's Inquiry Report. London. Government Stationary Office.

${ }^{3}$ L.Donaldson . 2001.Report of a census of organs and tissues retained by pathology services in England conducted in 2000. London. Government Stationary Office.

${ }^{4}$ J. Metters. 2003. Isaacs report: The investigation of events that followed the death of Cyril Mark Isaacs. London. Government Stationary Office.

${ }^{5}$ B. Parry; R. Zimmern; A. Hall; and K. Liddell. 2004. A Critique of the Human Tissue Bill - online publication available at: http://www.cgkp.org.uk/topics/human_tissue/bill_critique.pdf

${ }^{6}$ Explanatory Notes that accompany the Human Tissue Bill. Available at: $\bar{h}$ ttp://www.parliament.thestationery-office.co.uk/pa/cm200304/cmbills/009/en/04009x--.htm Section 13.

${ }^{7}$ Such as children, grandparents, wives or husbands.

${ }^{8}$ Findings of the King's College Brain Banking Bioethics project: forthcoming 2004/5. The findings of the Peterborough study confirm that of 3140 patients, $98.8 \%$ (3102) gave consent for surgically
} 
resected tissue to be used in research by commercial organisations, despite this being usually thought to be more troubling to patients than other sorts of research. Reported in P. Furness. 2003. Consent to using human tissue: Implied consent should suffice BMJ 2003; 327: 760-1.

${ }^{9}$ As recommended in Section 3.7 of the Human Bodies, Human Choices Summary Consultation Report. The Department of Health 2003.

${ }^{10}$ Professor Peter Furness is a diagnostic histopathologist working at the University Hospitals of Leicester and is a member of council of the Royal College of Pathologists

${ }^{11}$ Personal communication. The Leicester Pathology Service annual workload data figures are available at: http://www.pathology.plus.com/HTB/Leicester\%20annual\%20specimen\%20stats.htm

12 The Academy of Medical Sciences' Statement on the Human Tissue Bill, January 2004.

${ }^{13}$ Details available at: http://lombardi.georgetown.edu/research/resources/CMESR.htm

${ }^{14}$ W. Lowrance. 2002. Learning from Experience Privacy and the Secondary Use of Data in Health Research London. The Nuffield Trust. P. 30.

${ }^{15}$ Personal communication and Cambridge Genetics Knowledge Park and the Public Health Genetics Unit briefing paper on the revised version of the Human Tissue Bill available at: http://www.cgkp.org.uk/resources/pdf/htb_briefing.pdf

${ }^{16}$ A. Grubb. 1998. 'I, Me , Mine' Bodies, Parts and Property in Medical Law International 3: 299-317. p. 304 .

${ }^{17}$ A B and Others Vs. Leeds Teaching Hospital NHS Trust and Cardiff and Vale NHS Trust: Available online at http://www.courtservice.gov.uk/judgmentsfiles/j2427/ab-v-nhs_trusts.htm

Genomics, Society and Policy, Vol.1 No.1 (2005) ISSN: 1746-5354

(C) CESAGen, Lancaster University, UK. 